\title{
FAKTOR-FAKTOR YANG MEMPENGARUHI KEBIJAKAN DIVIDEN
}

\author{
Neni Meidawati \\ Universitas Islam Indonesia \\ neni.meidawati@uii.ac.id \\ Ahada Nurfauziya
Universitas Islam Indonesia \\ ahadanur@uii.ac.id \\ Uswatun Chasanah \\ Universitas Islam Indonesia \\ annachasanahh@gmail.com
}

\begin{abstract}
Abstrak: Faktor-Faktor yang Mempengaruhi Kebijakan Dividen. Investor memerlukan informasi yang dapat mendukung keputusannya untuk melakukan investasi, salah satunya melakukan analisis terhadap faktor yang mempengaruhi keputusan perusahaan dalam melakukan pembagian dividen. Tujuan dari penelitian melakukan analisis terhadap faktor-faktor yang mempengaruhi kebijakan dividen yaitu likuiditas, profitabilitas dan ukuran perusahaan. Populasi yang digunakan dalam penelitian ini adalah perusahaan manufaktur sektor industri makanan dan minuman yang terdaftar di Bursa Efek Indonesia (BEI) pada periode 2015-2017. Sampel penelitian berjumlah 12 perusahaan dengan menggunakan metode purposive sampling. Pengujian hipotesis, dianalisis dengan menggunakan metode regresi berganda. Hasil penelitian menunjukkan bahwa profitabilitas dan ukuran perusahaan berpengaruh positif signifikan terhadap kebijakan dividen, sedangkan likuiditas berpengaruh negatif signifikan.
\end{abstract}

Kata kunci: likuiditas, kebijakan dividen, profitabilitas, ukuran perusahaan

Abstract: Factors that Influence Dividend Policy. Investors need information that can support their decision to invest, one of which is to analyze the factors that influence the company's decision to distribute dividends. The purpose of the study is to analyze the factors that influence dividend policy, namely liquidity, profitability and company size. The population used in this study was manufacturing companies in the food and beverage industry sector which were listed on the Indonesia Stock Exchange (IDX) in the 2015-2017 period. The research sample consisted of 12 companies using a purposive sampling method. Hypothesis testing, analyzed using multiple regression methods. The results showed that profitability and firm size had a significant positive effect on dividend policy, while liquidity had a significant negative effect.

Keywords: liquidity, dividend policy, profitability, company size

\section{PENDAHULUAN}

Pasar modal merupakan pasar tempat untuk memperjual belikan surat-surat berharga baik dalam bentuk saham maupun obligasi (Aduardus dan Tandelilin, 2010). Pasar modal memiliki peran penting dalam memobilisasi dana dari investor yang ingin melakukan investasi di pasar modal. Banyak faktor yang berpengaruh terhadap kebijakan perusahaan untuk melakukan pembagian dividen. Analisis untuk mengetahui faktorfaktor yang berpengaruh terhadap pembagian dividen diperlukan, penelitian ini dilakukan untuk melakukan analisis terhadap faktor- 


\section{Nominal: Barometer Riset Akuntansi dan Manajemen}

P-ISSN: 2303-2065 E-ISSN: 2502-5430

Volume 9 No 2 (2020)

faktor yang mempengaruhi kebijakan dividen yaitu likuiditas, profitabilitas dan ukuran perusahaan. Penelitian dilakukan pada perusahaan manufaktur sektor makanan dan minuman yang terdaftar di Bursa Efek Indonesia, karena sektor industri makanan dan minuman merupakan industri yang masih mempunyai prospek di masa yang akan datang, dalam kondisi krisis sektor ini masih dapat bertahan untuk melanjutkan bisnisnya, sehingga masih menarik bagi investor. Berdasarkan data dari Badan Koordinasi Penanaman Modal (BKPM), selama periode Januari-Juni 2019 realisasi penanaman modal dalam negeri (PMDN) di sektor makanan menduduki peringkat keempat dari keseluruhan sektor dengan nilai Rp 21,26 triliun, sedangkan penanaman modal asing (PMA) menduduki peringkat keenam dengan nilai realisasi US\$706,7 juta (Bisnis.com). Pertumbuhan perekonomian di Indonesia masih di dominasi sektor manufaktur khususnya barang-barang konsumsi, diantaranya adalah industri makanan dan minuman. Berdasarkan survei Bank Indonesia pada tahun 2019 menunjukkan bahwa pertumbuhan ekonomi di masa yang akan datang mencapai 5,1 persen, dimana sektor konsumsi yang lebih berperan dalam pertumbuhan ekonomi di Indonesia, jika dibandingkan dengan sektor yang lain.
Kebijakan dividen dapat diketahui dengan melihat rasio Dividend Payout Ratio. Dividend Payout Ratio menentukan jumlah laba yang dapat ditahan oleh perusahaan sebagai sumber pendanaan. Besar kecilnya dividen yang dibayarkan dapat berpengaruh terhadap investor dalam membuat keputusan untuk melakukan investasi. Faktor-faktor yang berpengaruh terhadap Dividend Payout Ratio antara lain adalah likuiditas, profitabilitas dan ukuran perusahaan. Likuiditas diproksikan dengan Current Ratio (CR), Return on Assets (ROA) sebagai proksi profitabilitas dan ukuran perusahaan diproksikan dengan Firm Size.

Likuiditas merupakan rasio yang menggambarkan hubungan antara kas dan aset perusahaan lainnya dengan kewajibannya. Likuiditas akan tercermin dalam bentuk kemampuan perusahaan dalam membayar kewajiban tepat waktu. Likuiditas diartikan sebagai kemampuan perusahaan untuk memenuhi kewajiban jangka pendek perusahaan pada waktu yang ditentukan. Dividen merupakan arus kas keluar dalam perspektif perusahaan yang dapat berpengaruh terhadap posisi kas perusahaan (Brigham dan Houston, 2007; Prihadi, 2013). Menurut Darmawi dan Herman (2012), pengukuran likuiditas berupa perbandingan jumlah aset lancar dengan kebutuhan likuiditas yang diprediksikan. Semakin likuid sebuah perusahaan, maka pembayaran 


\section{Nominal: Barometer Riset Akuntansi dan Manajemen \\ P-ISSN: 2303-2065 E-ISSN: 2502-5430 \\ Volume 9 No 2 (2020)}

dividen yang dilakukan oleh perusahaan akan semakin besar. Penelitian yang telah dilakukan oleh Sari (2012) dan Afriani (2013) memperoleh bukti bahwa likuiditas tidak berpengaruh terhadap kebijakan dividen, sedangkan menurut Ahmad \& Wardani (2014) likuiditas berpengaruh negatif signifikan, namun hasil penelitian Dewi dan Sedana (2013), Sari dan Sudjarni (2015), Maladjian dan Khoury (2014) memperoleh bukti bahwa likuiditas berpengaruh positif signifikan.

Profitabilitas digunakan untuk mengetahui kemampuan perusahaan dalam menghasilkan laba atau seberapa efektif pengelolaan perusahaan oleh manajemen (Syahyunan, 2015). Laba perusahaan akan menjadi acuan dalam pembayaran dividen perusahaan. Semakin besar tingkat laba akan berpengaruh terhadap besaran tingkat pembayaran dividen yang akan dibagikan kepada pemegang saham. Profitabilitas akan menunjukkan besarnya laba yang diperoleh oleh perusahaan atas setiap investasi yang dilakukan oleh investor. Hasil penelitian Sari (2012), menyatakan bahwa profitabilitas tidak berpengaruh terhadap kebijakan dividen, sedangkan menurut Ayu (2013) berpengaruh signifikan, namun menurut Ahmad dan Wardani (2014), Ahmed (2015), Fitri et al., (2016), Marlim dan Arifin (2015), Moradi et al., (2010), Maladjian dan Khoury
(2014) menyatakan berpengaruh positif signifikan terhadap kebijakan dividen.

Ukuran perusahaan sebagai salah satu faktor penentu bagi investor dalam melakukan investasi, juga akan berpengaruh terhadap kebijakan dividen. Perusahaan dengan ukuran besar membayar dividen lebih tinggi, dan sebaliknya perusahaan dengan ukuran kecil akan membayar dividen lebih sedikit (Mehta, 2012). Karena perusahaan kecil lebih sulit mengumpulkan dana dari sumber internal dibandingkan dengan perusahaan besar. Penelitian Sisca (2008), Ahmad dan Wardani (2014), Maladjian dan Khoury (2014), Mehta (2012) menyatakan bahwa ukuran perusahaan berpengaruh positif terhadap kebijakan dividen, namun penelitian yang dilakukan oleh Sari (2012) dan Afriani (2013) memperoleh hasil bahwa ukuran perusahaan tidak berpengaruh terhadap kebijakan dividen.

Industri manufaktur merupakan industri yang cukup stabil dalam menopang perekonomian negara pada perekonomian dunia yang tidak pasti dengan menunjukkan tingkat pertumbuhan yang positif. Salah satunya yaitu sektor industri makanan dan minuman yang mempunyai peluang untuk tumbuh dan berkembang. Kondisi tersebut terlihat dengan semakin menjamurnya industri makanan dan minuman di dalam negeri, sehingga memicu persaingan yang semakin ketat dan akibatnya para manajer 


\section{Nominal: Barometer Riset Akuntansi dan Manajemen \\ P-ISSN: 2303-2065 E-ISSN: 2502-5430 \\ Volume 9 No 2 (2020)}

perusahaan bersaing ketat dalam mencari investor untuk berinvestasi.

Kebijakan dividen diartikan sebagai kebijakan dalam penentuan berapa jumlah dari laba bersih yang hendak dibagikan kepada pemegang saham sebagai bentuk pembayaran dividen dan berapa jumlah laba bersih yang nantinya dilakukan investasi ulang pada perusahaan sebagai laba ditahan guna memperoleh capital gains (Deitiana, 2011). Dividen sebagai pembayaran dari hasil pendapatan perusahaan atau distribusi dari keuntungan perusahaan yang dibagikan kepada pemegang saham berupa kas atau saham (Ahmad dan Wardani, 2014). Dewan komisaris memiliki kewenangan dalam memutuskan pembayaran dividen tunai kepada pemegang saham perusahaan.

Barang kebutuhan konsumsi menjadi industri yang cukup penting bagi perkembangan perekonomian negara. Jumlah perusahaan manufaktur sektor makanan dan minuman yang telah terdaftar di Bursa Efek Indonesia (BEI) diketahui memiliki jumlah yang cukup banyak jika dibandingkan dengan perusahaan di sektor lainnya. Oleh karena itu perusahaan manufaktur sektor makanan dan minuman dipilih sebagai objek penelitian.

\section{KAJIAN LITERATUR}

\section{A. Teori Agensi}

Jensen dan Meckling (1976) menjelaskan teori keagenan sebagai bentuk kontrak antara manajer sebagai agen dan pemilik perusahaan sebagai prinsipal. Untuk menjaga hubungan antara manager dan pemilik perusahaan agar dapat berjalan dengan baik, pemilik akan menyerahkan kewenangan dalam pengambilan keputusan kepada pihak manajer. Teori keagenan memiliki beberapa asumsi yang menjadi landasannya. Asumsi tersebut dikelompokkan menjadi tiga jenis, yakni asumsi atas sifat dasar manusia, asumsi atas keorganisasian, dan asumsi atas informasi. Asumsi atas sifat dasar manusia menegaskan bahwa perilaku manusia cenderung mementingkan diri sendiri (self interest), memiliki pemikiran yang terbatas terkait persepsi masa yang akan datang (bounded rationality), dan sebaiknya memilih untuk menghindari risiko (risk averter). Asumsi keorganisasian menunjukkan terdapatnya konflik diantara anggota organisasi, pemahaman efisiensi sebagai ciri efektivitas, dan asimetri informasi yang terjadi diantara manajer dan pemilik. Asumsi informasi mengindikasikan bahwa informasi sebagai komoditas yang dapat diperjual-belikan.

Penjelasan mengenai asumsi atas sifat dasar manusia, mengindikasikan bahwa antara pemilik perusahaan dan manajer cenderung lebih mengedepankan kepentingan diri sendiri. Pemilik memiliki motivasi untuk mengikat kontrak guna memperoleh keuntungan dengan 


\section{Nominal: Barometer Riset Akuntansi dan Manajemen}

P-ISSN: 2303-2065 E-ISSN: 2502-5430

Volume 9 No 2 (2020)

peningkatan profitabilitas yang signifikan, sedangkan manajer memiliki motivasi untuk memaksimalkan pemenuhan dari kebutuhan ekonomi dan psikologis dengan memperoleh dana investasi, pinjaman, maupun kontrak kompensasi. Sehingga dapat diidentifikasi terdapat 2 (dua) kepentingan yang berbeda antara agen dan principal.

Permasalahan yang diakibatkan dari munculnya perbedaan kepentingan antara agen dan prinsipal disebut dengan agency problems. Penyebab agency problems salah satunya adalah terdapatnya asimetri informasi. Asimetri informasi merupakan tidak seimbangnya informasi yang dimiliki antara agen dan prinsipal, permasalahan tersebut terjadi ketika pemilik tidak memperoleh informasi yang cukup terhadap kondisi perusahaan dan kinerja manajemen, dilain pihak manajer sebagai pelaksana mengetahui lebih banyak mengenai informasi dari lingkungan perusahaan, kapasitas diri, serta kondisi perusahaan secara menyeluruh.

\section{B. Teori Kebijakan Dividen}

Ada beberapa teori yang dapat dijadikan landasan dalam penentuan kebijakan dividen untuk perusahaan. Salah satunya adalah (Syahyunan, 2015), teori "The Bird in the Hand". Teori ini dikemukakan oleh Myron J. Gordon dan John Lintner yang menyatakan bahwa biaya dari modal perusahaan akan naik jika Dividend Payout Ratio-nya rendah dikarenakan investor cenderung lebih memilih untuk menerima dividen daripada capital gain. Investor lebih tertarik terhadap dividen dibandingkan dengan capital gain.

Teori ini memandang bahwa return investasi saham bisa dalam bentuk dividen atau capital gain. Selisih lebih antara harga jual dan harga beli saham merupakan keuntungan yang dapat diperoleh investor disebut dengan capital gain. Teori ini menyatakan bahwa return dalam bentuk dividen lebih memiliki kepastian dan dapat diprediksi jika dibandingkan dengan capital gain. Selain hal tersebut karena capital gain lebih bersifat spekulasi karena dipengaruhi oleh perubahan harga saham yang dapat setiap saat akan berubah-ubah bersifat fluktuatif, serta tergantung pergerakan pasar modal sehingga perusahaan tidak bisa mengendalikan. Disamping hal tersebut dividen memiliki resiko yang lebih kecil dibandingkan dengan capital gain, sehingga investor lebih tertarik dengan dividen.

\section{Likuiditas}

Sitanggang (2012) mengemukakan bahwa likuiditas menjadi ukuran kinerja dari kemampuan perusahaan guna memenuhi kewajiban keuangan lancar yang segera harus dilunasi yaitu kewajiban keuangan dengan jatuh tempo hingga satu tahun. Perusahaan dikatakan dalam keadaan likuid pada saat perusahaan mampu untuk memenuhi kewajiban keuangan tepat waktu. 


\section{Nominal: Barometer Riset Akuntansi dan Manajemen \\ P-ISSN: 2303-2065 E-ISSN: 2502-5430 \\ Volume 9 No 2 (2020)}

Hanya perusahaan dengan kondisi likuid yang mampu membayarkan dividen kepada para pemegang saham, dalam bentuk pembayaran tunai. Manajemen perusahaan pada umumnya menggunakan likuiditas untuk membayar kewajiban jangka pendeknya.

\section{Profitabilitas}

Rasio Profitabilitas diartikan sebagai rasio untuk penilaian kemampuan perusahaan dalam menghasilkan keuntungan dari proses penjualan, pengelolaan asset dan penggunaan modal dari saham tertentu. Sehingga rasio ini memberikan gambaran atau sebagai ukuran tingkat efektivitas manajemen perusahaan. Maka penggunaan rasio profitabilitas menjadi gambaran efisiensi pada perusahaan (Munawir, 2010). Profitabilitas terdiri dari 2 (dua) jenis rasio yaitu rasio dalam hubungannya dengan penjualan dan rasio yang menunjukkan profitabilitas dengan aktivitas investasi.

\section{E. Ukuran Perusahaan (Firm Size)}

Ukuran perusahaan adalah salah satu indikator yang berpengaruh terhadap risiko bisnis dengan pengukuran menggunakan total dari aset perusahaan, penjualan dan ekuitas (Yanti, 2014). Perusahaan yang besar serta memiliki akses pasar yang lebih luas akan mampu membayar dividen kepada pemegang saham dikarenakan kemampuan perusahaan dalam mendapatkan dana dalam waktu yang relatif cepat. Perusahaan dengan ukuran yang besar mengindikasikan kemampuan dalam menghasilkan laba yang tinggi sehingga mampu membayarkan dividen yang tinggi kepada pemegang saham. Ukuran perusahaan diproksikan dengan Firm Size.

\section{F. Pengembangan Hipotesis}

Likuiditas merupakan kemampuan sebuah perusahaan dalam memenuhi kewajiban jangka pendek pada saat jatuh tempo. Investor dalam melakukan analisa terhadap laporan keuangan untuk mengetahui kondisi keuangan perusahaan dapat dilihat dari current ratio. Semakin tinggi current ratio, semakin baik karena dapat diindikasikan bahwa perusahaan mampu membayar kewajiban jangka pendeknya. Sehingga likuiditas diproksikan dengan current ratio yang merupakan rasio lancar. Teori "Bird in the hand" menyatakan bahwa pembayaran dividen akan mengurangi ketidakpastian dan risiko yang dihadapi investor. Sesuai dengan teori ini perusahaan harus mampu membagikan dividen kepada investor dan diperlukan ketersediaan dana dalam hal ini kas yang dimiliki perusahaan. Perusahaan harus dalam keadaan likuid untuk memenuhi hal tersebut. Dewi dan Panji (2013), Sari dan Sudjarni (2015), Maladjian dan Khoury (2014), menyatakan bahwa likuiditas berpengaruh positif signifikan terhadap kebijakan dividen. Perusahaan dengan posisi kas dan likuiditas yang semakin besar secara 


\section{Nominal: Barometer Riset Akuntansi dan Manajemen}

P-ISSN: 2303-2065 E-ISSN: 2502-5430

Volume 9 No 2 (2020)

keseluruhan mengindikasikan semakin besar kemampuan perusahaan untuk membayar dividen (Yanti, 2014). Berdasar hasil penelitian menunjukkan bahwa semakin besar kondisi likuiditas suatu perusahaan mengindikasikan semakin besar kemampuan perusahaan untuk melakukan pembayaran dividen. Oleh karena itu, likuiditas diprediksi berpengaruh positif terhadap kebijakan dividen.

Return on Assets (ROA) merupakan rasio keuangan yang digunakan untuk mengukur tingkat pengembalian aktiva yang telah digunakan untuk menghasilkan laba. Perusahaan dengan rasio Return on Assets (ROA) yang tinggi mengindikasikan kinerja perusahaan yang semakin baik, karena diasumsikan tingkat pengembalian investasi semakin besar. Sehingga besaran peningkatan Return on Assets juga akan meningkatkan besaran dari pendapatan dividen. Ahmed (2015), Fitri et al., (2016), Marlim dan Arifin (2015), Moradi et al., (2010), dan Maladjian dan Khoury (2014) mengungkapkan bahwa Return on Assets berpengaruh positif terhadap kebijakan dividen.

Ukuran perusahaan merupakan salah satu indikator yang dapat berpengaruh terhadap risiko bisnis dengan menggunakan total dari asset perusahaan, penjualan dan ekuitas. Perusahaan yang besar serta memiliki akses pasar yang lebih luas akan mampu membayar dividen kepada pemegang saham dikarenakan kemampuan perusahaan dalam mendapatkan dana dalam waktu yang relatif cepat. Perusahaan dengan ukuran yang besar mengindikasikan kemampuan dalam menghasilkan laba yang tinggi sehingga mampu membayarkan dividen yang tinggi kepada pemegang saham. Ukuran perusahaan diproksikan dengan Firm Size. Ahmad dan Wardani (2014), Maladjian dan Khoury (2014), Mehta (2012), mengungkapkan Firm Size memiliki pengaruh positif dan signifikan terhadap kebijakan dividen. Karena itulah, ukuran perusahaan diprediksi memiliki pengaruh positif terhadap kebijakan dividen perusahaan.

H1: Likuiditas berpengaruh positif terhadap kebijakan dividen.

H2: Profitabilitas berpengaruh positif terhadap kebijakan dividen.

H3: Ukuran Perusahaan berpengaruh positif terhadap kebijakan dividen.

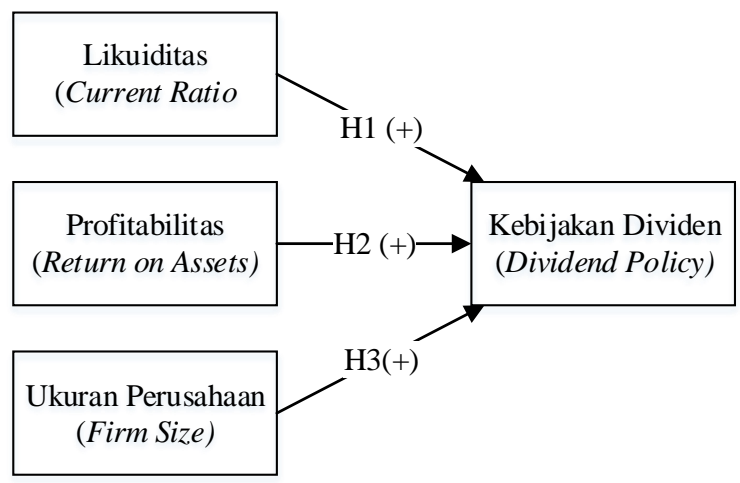

Gambar 1. Kerangka Pemikiran 


\section{METODE PENELITIAN}

\section{A. Populasi, Sampel dan Sumber Data}

Populasi dalam penelitian ini, perusahaan manufaktur sektor industri makanan dan minuman yang terdaftar di Bursa Efek Indonesia (BEI) pada periode 2015-2017, dengan kriteria sampel sebagai berikut:

1. Perusahaan manufaktur sektor industri makanan dan minuman yang terdaftar di BEI periode tahun 2015-2017.

2. Periode pelaporan tahunan keuangan perusahaan yang berakhir pada 31 Desember dan pelaporan keuangan yang dinyatakan dalam rupiah.

3. Perusahaan manufaktur sektor industri makanan dan minuman telah mengumumkan laporan keuangan secara berkelanjutan selama pelaporan tahunan periode 2015- 2017.

4. Perusahaan manufaktur sektor industri makanan dan minuman yang membayarkan dividen secara berturutturut selama periode tahun 2015- 2017.

Data diperoleh dari perusahaan manufaktur yang terdaftar di BEI yaitu perusahaan manufaktur sektor industri makanan dan minuman periode 2015-2017. Sumber data diperoleh dari www.idx.co.id.

\section{B. Variabel Dependen}

Kebijakan dividen (dividend policy) merupakan variabel dependen. Pengukuran menggunakan Dividen Payout Ratio.
Dividen merupakan porsi pembayaran atas pendapatan perusahaan atau distribusi dari perolehan keuntungan kepada pemegang saham dengan bentuk pembayaran kas atau saham (Ahmad dan Wardani, 2014).

Dividend Payout Ratio

$$
=\frac{\text { Dividend per Share }}{\text { Earning per Share }}
$$

\section{Variabel Independen}

Ada tiga variabel independent yaitu likuiditas, profitabilitas, dan ukuran perusahaan (firm size). Sitanggang (2012) mengemukakan bahwa likuiditas menjadi ukuran kinerja dari kemampuan perusahaan guna memenuhi kewajiban keuangan lancar (yang segera harus dilunasi) yakni kewajiban keuangan dengan jatuh tempo hingga 1 tahun. Pengukuran variabel likuiditas menggunakan current ratio $(C R)$. Perhitungan Current ratio dengan perbandingan antara aset lancar perusahaan dengan utang lancar perusahaan.

$$
\text { Current Ratio }=\frac{\text { Aktiva Lancar }}{\text { Hutang Lancar }}
$$

Rasio Profitabilitas diartikan sebagai rasio untuk penilaian kemampuan perusahaan dalam menghasilkan keuntungan (profit) dari proses penjualan, pengelolaan asset dan penggunaan modal dari saham tertentu. Sehingga rasio ini memberikan gambaran atau sebagai ukuran tingkat efektivitas manajemen perusahaan. Maka penggunaan rasio profitabilitas menjadi gambaran efisiensi pada perusahaan (Munawir, 2010). 


\section{Nominal: Barometer Riset Akuntansi dan Manajemen}

P-ISSN: 2303-2065 E-ISSN: 2502-5430

Volume 9 No 2 (2020)

Pengukuran variabel profitabilitas menggunakan rasio Return on Asset (ROA). Perhitungan ROA dengan perbandingan antara laba bersih dengan total aset yang dimiliki perusahaan.

$$
\text { Return on Asset }(R O A)=\frac{\text { Laba Bersi } \bigotimes}{\text { Total Asset }}
$$

Ukuran perusahaan adalah salah satu variabel akuntansi yang berpengaruh terhadap risiko bisnis yang dapat diukur dengan menggunakan total aset, penjualan dan ekuitas (Yanti, 2014). Pengukuran variabel ini dengan menggunakan total aset yang dimiliki oleh perusahaan yang ditujukan untuk membayar dividen kepada seluruh pemegang saham. Perhitungan variabel ukuran perusahaan dalam penelitian ini diukur dengan menggunakan Firm Size.

$$
\text { Size }=\text { LN Total Asset }
$$

\section{Model Regresi Data Panel}

Pengujian regresi dengan menggunakan data panel dilakukan melalui tiga pendekatan model regresi, yaitu Common Effect Models (CEM), Fixed Effect Models (FEM) dan Random Effect Models (REM). Pengujian pertama untuk menentukan apakah permodelan dengan pendekatan fixed effect model (FEM) atau common effect model (CEM) yang paling tepat digunakan untuk mengestimasi data panel, dilakukan dengan Uji chow. Apabila nilai Chi-Square yang dihasilkan dengan metode ini di bawah 0,05 dengan tingkat signifikasi $\alpha=5 \%$ maka dapat disimpulkan fixed effect model (FEM) lebih baik atau lebih tepat dibandingkan common effect model (CEM).

Pengujian statistik kedua dilakukan untuk memilih apakah model fixed effect (FEM) atau model random effect (REM) yang paling tepat digunakan, dilakukan dengan uji hausman. Apabila hasil uji Hausman memperoleh nilai Chi Square lebih kecil dari 0,05 dengan tingkat signifikasi $\alpha=5 \%$, maka hal tersebut menunjukkan bahwa fixed effect model (FEM) yang lebih tepat dibandingkan random effect model (REM).

Pengujian terakhir dalam pemilihan permodelan regresi untuk mengetahui apakah model random effect (REM) lebih baik dari pada metode common effect (OLS) dilakukan dengan Uji lagrange multiplier (LM).

Pada pelaksanaan pengujian regresi data panel tidak selalu dilakukan ketiga uji tersebut, ketika peneliti menemukan terdapat perbedaan intersep yang terjadi antar perusahaan maka model common effect akan diabaikan sehingga hanya dilakukan uji hausman pada pengujian lanjutan. Pemilihan model fixed effect atau random effect dilakukan dengan mempertimbangkan jumlah waktu dan individu pada penelitian. Menurut Nachrowi dan Hardius (2006), beberapa ahli ekonometri telah membuktikan secara matematis, di mana dikatakan bahwa: 


\section{Nominal: Barometer Riset Akuntansi dan Manajemen}

P-ISSN: 2303-2065 E-ISSN: 2502-5430

Volume 9 No 2 (2020)

1) Jika data panel yang dimiliki mempunyai jumlah waktu $(\mathrm{T})$ lebih besar dibanding jumlah individu (N) maka disarankan untuk menggunakan model fixed effect.

2) Jika data panel yang dimiliki mempunyai jumlah waktu (T) lebih kecil dibanding jumlah individu (N) maka disarankan untuk menggunakan model random effect.

$$
\mathrm{Y}=\alpha+\beta_{1} X_{1}+\beta_{2} X_{2}+\beta_{3} X_{3}+e
$$

Keterangan:

$$
\begin{array}{ll}
\mathrm{Y} & =\text { Kebijakan dividen } \\
\alpha & =\text { konstanta } \\
\mathrm{b} 1, \mathrm{~b}_{2}, \mathrm{~b}_{3},= & \text { koefisien regresi masing-masing } \\
& \text { variabel bebas } \\
\mathrm{X} 1 & =\text { Likuiditas } \\
\mathrm{X} 2 & =\text { Profitabilitas } \\
\mathrm{X} 3 & =\text { Ukuran Perusahaan } \\
\mathrm{e} & =\text { error atau tingkat kesalahan }
\end{array}
$$

\section{HASIL PENELITIAN DAN}

\section{PEMBAHASAN}

Hasil

Jumlah perusahaan manufaktur untuk sektor makanan dan minuman berjumlah 18 perusahaan, namun dalam pengambilan sampel penelitian terdapat 6 perusahaan yang tidak memenuhi kriteria yang ditentukan dalam penelitian ini, karena empat (4) perusahaan tersebut memiliki tanggal IPO di tahun 2017 sehingga belum memenuhi kriteria sampel dalam penelitian ini yang memerlukan pelaporan perusahaan periode 2015-2017. Sedangkan dua (2) perusahaan

lainnya tidak memenuhi kriteria terkait pelaporan data kebijakan dividen.

\section{A. Analisis Data Penelitian \\ 1). Model Common effect}

Hasil pengujian regresi dengan menggunakan model common effect dapat dilihat pada tabel berikut:

Tabel 1. Model Common effect

\begin{tabular}{ccccc}
\hline Variabel & $\begin{array}{c}\text { Koefisi } \\
\text { en }\end{array}$ & $\begin{array}{c}\text { Std. } \\
\text { Error }\end{array}$ & t & Prob. \\
\hline C & $-5,37140,8730$ & $-6,1524$ & 0,0000 \\
CR & 0,1466 & 0,1350 & 1,0859 & 0,2856 \\
ROA & 6,8199 & 0,7056 & 9,6647 & 0,0000 \\
SIZE & 1,1282 & 0,0565 & 19,941 & 0,0000 \\
R-squared & 0,9375 & & & \\
Adjusted R- & & & & \\
squared & 0,9316 & & \\
F-statistic & 160,06 & & \\
Prob(F-statistic) & 0,0000 & & \\
Sumber: Hasil Olah Data 2019 & &
\end{tabular}

\section{2). Model Fixed effect}

Hasil pengujian regresi dengan menggunakan model fixed effect dapat dilihat pada tabel berikut:

Tabel 2. Model Fixed Effect

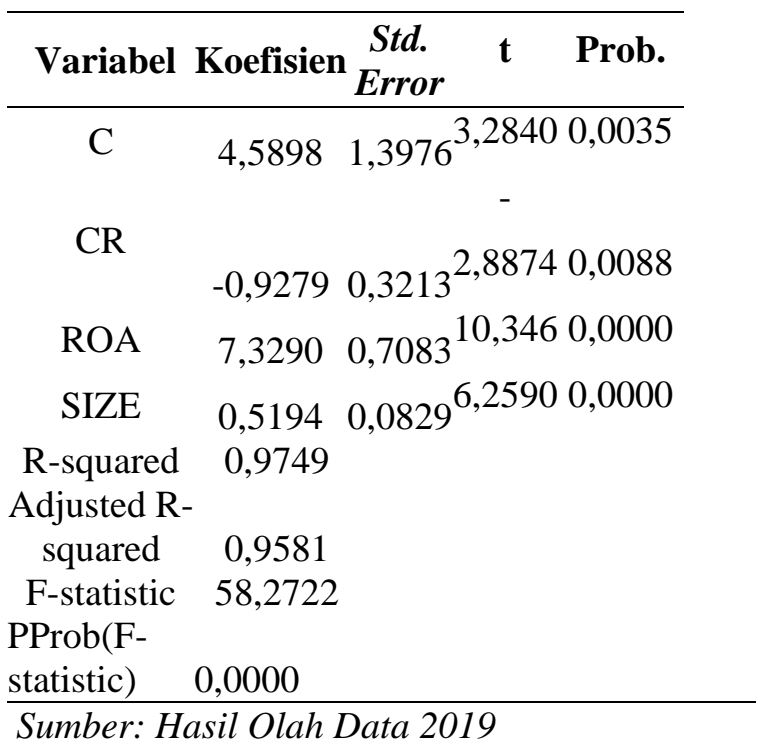




\section{3) Model Random Effect}

Hasil pengujian regresi dengan menggunakan model random effect dapat dilihat pada tabel berikut:

Tabel 3. Model Random Effect

\begin{tabular}{lllll} 
Variabel & Koefisien & $\begin{array}{c}\text { Std. } \\
\text { Error }\end{array}$ & $\mathbf{t}$ & Prob. \\
\hline C & $-5,0500$ & 1,0397 & 4,8568 & 0,0000 \\
CR & 0,0417 & 0,1550 & 0,2690 & 0,7896 \\
ROA & 6,6134 & 0,7238 & 9,1363 & 0,0000 \\
SIZE & 1,1135 & 0,0677 & 16,438 & 0,0000 \\
R-squared & 0,8967 & & & \\
Adjusted R- & & & & \\
squared & 0,8870 & & & \\
F-statistic & 92,654 & & & \\
Prob(F- & & & & \\
statistic) & 0,0000 & & & \\
\hline Sumber:Hasil &
\end{tabular}

Sumber: Hasil Olah Data 2019

\section{B. Pemilihan Model Regresi}

Pemilihan model regresi data panel dapat diketahui setelah melalui beberapa pengujian seperti Uji Chow dan Uji Haustman (Widarjono, 2007).

\section{1). Uji Chow}

Uji Chow dilakukan untuk menentukan apakah common effect model (CEM) yang tepat dijadikan metode analisis, atau fixed effect model (FEM).

Tabel 4. Hasil Uji Chow

\begin{tabular}{|c|c|c|}
\hline Effects Test & Statistik & d.f. Prob. \\
\hline $\begin{array}{l}\text { Cross-section F } \\
\text { Cross-section }\end{array}$ & 2,8437 & $(11,21) 0,0190$ \\
\hline $\begin{array}{l}\text { Chi- } \\
\text { square }\end{array}$ & 32,8363 & 110,0006 \\
\hline
\end{tabular}

Sumber: Hasil Olah Data 2019

Berdasarkan hasil uji Chow terhadap model regresi yang dilakukan diketahui nilai probabilitas Chi-Square sebesar 0,0006 pada tingkat signifikansi $\alpha=5 \%$ dimana perolehan nilai Chi-Square yang dihasilkan di bawah 0,05. Dengan demikian kesimpulan yang dapat diambil yaitu model fixed effect lebih baik atau lebih tepat dibandingkan common effect model.

\section{2). Haustman test}

Pada pengujian model dengan uji Chow diperoleh model fixed effect model (FEM) sebagai model regresi yang relevan, maka pengujian tahapan selanjutnya dilakukan dengan Uji Hausman dan merupakan pengujian tahapan terakhir guna menentukan apakah random effect model (REM) yang tepat dijadikan metode analisis, atau fixed effect model (FEM).

Tabel 5. Hasil Uji Haustman

\begin{tabular}{cccc}
\hline Test Summary & $\begin{array}{c}\text { Chi-Sq. } \\
\text { Statistic }\end{array}$ & $\begin{array}{c}\text { Chi- } \\
\text { Sq. }\end{array}$ & Prob. \\
d.f. & \\
\hline Cross-section random & 11,1019 & 3 & 0,0112 \\
\hline \multicolumn{4}{c}{ Sumber: Hasil Olah Data 2019} \\
\hline
\end{tabular}

Berdasarkan hasil uji Hausman di atas diketahui nilai Chi-Square diperoleh sebesar 0,0112 pada tingkat signifikansi $\alpha=5 \%$. Hasil tersebut menunjukkan bahwa fixed effect model yang lebih tepat dibandingkan random effect model karena perolehan nilai Chi Square lebih kecil dari 0,05.

Hasil uji asumsi klasik menunjukkan bahwa data normal, bersifat homoskedastisitas atau tidak terjadi 
Nominal: Barometer Riset Akuntansi dan Manajemen

P-ISSN: 2303-2065 E-ISSN: 2502-5430

Volume 9 No 2 (2020)

heterokedastisitas, dan tidak ada multikolinearitas.

\section{Pengujian Hipotesis Penelitian}

Berdasarkan hasil uji kelayakan model, diketahui bahwa model Fixed effect yang paling tepat digunakan pada penelitian ini untuk menjawab hipotesis penelitian.

Tabel 6. Hasil Pengujian Hipotesis dengan Model Fixed Effect

\begin{tabular}{|c|c|c|c|}
\hline Model & $\begin{array}{c}\text { Koefisien } \\
\text { Regresi }\end{array}$ & Signifikansi & Kesimpulan \\
\hline (Constant & 4,5899 & 0,0035 & \\
\hline $\mathrm{CR}$ & $-0,9279$ & 0,0088 & H1 ditolak \\
\hline ROA & 7,3291 & 0,0000 & $\begin{array}{l}\mathrm{H} 2 \text { gagal } \\
\text { ditolak }\end{array}$ \\
\hline SIZE & 0,5194 & 0,0000 & $\begin{array}{l}\text { H3 gagal } \\
\text { ditolak }\end{array}$ \\
\hline
\end{tabular}

Sumber: Hasil Olah Data 2019

$$
\begin{gathered}
Y=4,5899-0,9279 X_{1}+7,3291 X_{2}+ \\
0,5194 X_{3}+e
\end{gathered}
$$

\section{Pembahasan}

\section{A. Pengaruh Likuiditas Perusahaan terhadap Kebijakan Dividen}

Hasil penelitian ini menunjukkan variabel likuiditas (X1) memiliki nilai koefisien regresi $-0,9279$ bernilai negatif dengan nilai $P$ Value sebesar 0,0088 , hal ini menunjukkan bahwa likuiditas berpengaruh negatif terhadap kebijakan dividen, sehingga hipotesis pertama yang menyatakan bahwa likuiditas berpengaruh positif terhadap kebijakan dividen ditolak.

Penelitian dilakukan pada sektor industri makanan dan minuman, yang merupakan sektor utama untuk memenuhi kebutuhan

hidup, sehingga investor dalam pengambilan keputusan tidak semata-mata memperhatikan tingkat likuiditasnya, terkait dengan deviden yang akan diterima. Hal ini ini terlihat pada laporan keuangan yang merupakan sampel penelitian menunjukkan bahwa dengan tingkat likuiditas di tahun 2016 sebesar 1,3153 perusahaan membagi dividen dengan ratio 8,16 lebih tinggi, dibanding tahun 2015 dengan likuiditas 1,1925 dan pembagian dividen dengan ratio 0,91 .

Perusahaan yang memiliki tingkat likuiditas yang rendah akan cenderung membagikan dividen yang tinggi kepada pemegang saham dan sebaliknya. Kondisi tersebut dapat dijelaskan dengan teori signaling (Megginson, 1977) bahwasanya pada kondisi likuiditas rendah, akan tetapi perolehan tingkat profitabilitasnya tinggi, perusahaan tidak memiliki cukup kas untuk membagikan dividen dalam bentuk kas, sehingga sebagai gantinya perusahaan akan membagikan dividen dalam bentuk saham (stock dividend) untuk menunjukkan kepada pemegang saham bahwasanya perusahaan masih memiliki kinerja yang baik dalam menghasilkan keuntungan.

Persoalan pembayaran dividen yang kaitannya dengan likuiditas bisa di pahami dengan mengacu kepada teori mengenai dividen yang dinyatakan oleh Brealey, Myres, dan Marcus (2007). Likuiditas mampu menjadi patokan untuk menunjukkan 


\section{Nominal: Barometer Riset Akuntansi dan Manajemen \\ P-ISSN: 2303-2065 E-ISSN: 2502-5430 \\ Volume 9 No 2 (2020)}

kemampuan perusahaan untuk membayar dividen namun bukan berarti kelancaran pembayaran hutang jangka pendeknya, dimana hal tersebut akan mengindikasikan perusahaan pasti akan membayarkan dividen kepada pemegang saham. Persoalan tersebut bisa saja disebabkan pertimbangan lain seperti perancangan peluang investasi, pembatasan pembayaran dividen atau estimasi dari melakukan pembayaran dividen akan berdampak kepada kinerja perusahaan selanjutnya (Brigham dan Houston, 2007). Berbeda dengan hasil penelitian yang diperoleh Dewi \& Sedana (2013), Sari \& Sudjarni (2015), dan Maladjian dan Khoury (2014), menemukan bahwa variabel likuiditas berpengaruh positif terhadap kebijakan dividen, sehingga memunculkan asumsi dengan posisi likuiditas yang semakin besar pada suatu perusahaan akan berakibat semakin besar kemampuan persahaan untuk melakukan pembayaran dividen. Dalam membayar dividen perusahaan membutuhkan aliran kas keluar, sehingga harus tersedia likuiditas yang cukup. Pada current ratio terdapat kas sebagai salah satu sumber untuk pembayaran dividen, namun besarnya current ratio tidak selalu dipengaruhi oleh kondisi kas perusahaan saja namun dipengaruhi juga oleh beberapa akun seperti piutang usaha dan persediaan barang. Hasil penelitian ini mendukung penelitian yang dilakukan oleh Ahmad \& Wardani
(2014) yang menyatakan bahwa likuiditas berpengaruh negatif signifikan terhadap kebijakan dividen.

\section{B. Pengaruh Profitabilitas terhadap Kebijakan Dividen}

Hasil pengujian regresi, variabel profitabilitas (X2) memiliki nilai koefisien regresi 7,3291 dan $P$ Value 0,0000, hal ini menunjukkan bahwa profitabilitas berpengaruh positif dan signifikan terhadap kebijakan dividen, sehingga hipotesis kedua yang menyatakan bahwa profitabilitas berpengaruh positif terhadap kebijakan dividen gagal ditolak.

Hasil penelitian ini menunjukkan bahwa profitabilitas berpengaruh positif signifikan terhadap kebijakan dividen, sehingga tingginya profitabilitas akan membawa dampak terhadap ketertarikan minat investor untuk menanamkan modalnya di perusahaan yang mengharapkan akan mendapatkan keuntungan yang tinggi dari investasinya. Hal ini menunjukkan bahwa investor yang melakukan investasi pada perusahaan makanan dan minuman masih mempertimbangkan pengambilan keputusannya berdasarkan tingkat profitabilitas, karena harapan investor semakin tingkat profitabilitas, maka deviden yang diperoleh semakin tinggi. Hal ini terbukti dari sampel perusahaan yang diteliti dari laporan keuangannya pada tahun 2016 


\section{Nominal: Barometer Riset Akuntansi dan Manajemen}

P-ISSN: 2303-2065 E-ISSN: 2502-5430

Volume 9 No 2 (2020)

dengan tingkat profitabilitas 0,1041 memiliki rasio pembagian dividen sebesar 0,96 dan tahun 2017 dengan tingkat profitabilitas 0,1053 memiliki rasio pembagian dividen sebesar 0,97. Hal ini membuktikan bahwa ada pengaruh positif antara profitabilitas dengan pembagian deviden. Industri makanan dan minuman merupakan satu dari lima sektor manufaktur yang diprioritaskan pengembangannya di era industri 4,0, sehingga dapat bersaing dalam skala internasional. Pada masa pandemi covid 19, salah satu sektor yang dapat bertahan adalah perusahaan di sektor makanan dan minuman, yang merupakan sektor yang diharapkan dapat mendorong pertumbuhan ekonomi. Oleh karena itu sektor makanan dan minuman yang masih mempunyai harapan untuk berkembang dan meraih tingkat profitabilitas yang tinggi. Hal ini juga didukung dari informasi laporan keuangan dan laporan tahunan PT. Mayora Indah Tbk menunjukkan peningkatan profitabilitas dari tahun ke tahun, yang diikuti dengan kenaikan deviden. Rasio profitabilitas lebih cenderung menjadi sorotan oleh para pemegang saham dan manajemen perusahaan sebagai salah satu alat dalam pengambilan keputusan investasi, sehingga para investor mampu memutuskan apakah investasi bisnis ini akan dikembangkan, dipertahankan, dan sebagainya. Rasio Profitabilitas yang digunakan untuk mengukur tingkat efektivitas pengelolaan manajemen perusahaan yang ditunjukkan dengan jumlah keuntungan yang mampu dihasilkan perusahaan dari penjualan dan investasi seperti profit margin, earning power, return on total assets, return on equity, dan return on investment.

Kondisi tersebut sesuai dengan pendapat Hendra (2009) bahwasanya rasio profitabilitas sebagai pengukur kemampuan para eksekutif perusahaan dalam mendapatkan tingkat keuntungan, apakah dalam bentuk dana perusahaan maupun nilai ekonomis atas penjualan, aset bersih perusahaan maupun modal sendiri (shareholder equity). Kemampuan perusahaan untuk membayar dividen merupakan fungsi dari keuntungan. Pihak manajemen akan membayarkan dividen untuk memberikan gambaran mengenai keberhasilan perusahaan dalam membukukan profit perusahaan. Tindakan manajemen tersebut memberikan kesimpulan bahwa kemampuan perusahaan untuk membayar dividen merupakan bentuk fungsi dari penggunaan keuntungan perusahaan. Perusahaan dengan perolehan keuntungan usaha akan cenderung membayarkan dividen kepada pemegang saham. Sehingga dapat diasumsikan bahwa kondisi dimana semakin besarnya keuntungan yang diperoleh perusahaan maka akan memberikan dampak 


\section{Nominal: Barometer Riset Akuntansi dan Manajemen \\ P-ISSN: 2303-2065 E-ISSN: 2502-5430 \\ Volume 9 No 2 (2020)}

semakin besar pula kemampuan perusahaan untuk membayar dividen (Suharli, 2006).

Hasil penelitian ini mendukung penelitian yang dilakukan oleh Ahmad dan Wardani (2014), Ahmed (2015), Fitri et al., (2016), Marlim dan Arifin (2015), Moradi et al., (2010), dan Maladjian dan Khoury (2014) yang membuktikan bahwa berpengaruh positif signifikan terhadap kebijakan dividen, namun tidak mendukung penelitian yang dilakukan oleh Sari (2012), yang menyatakan bahwa profitabilitas tidak berpengaruh terhadap kebijakan dividen.

\section{Pengaruh Ukuran Perusahaan terhadap}

\section{Kebijakan Dividen}

Hasil pengujian regresi variabel ukuran perusahaan (X3) memiliki nilai koefisein regresi 0,5194 dan $P$ Value 0,0000, hal ini menunjukkan bahwa ukuran perusahaan berpengaruh positif dan signifikan terhadap kebijakan dividen, sehingga hipotesis ketiga yang menyatakan bahwa ukuran perusahaan berpengaruh positif terhadap kebijakan dividen gagal ditolak.

Hasil penelitian ini menunjukkan bahwa ukuran perusahaan berpengaruh positif signifikan terhadap kebijakan dividen. Pada perusahaan dengan ukuran yang besar akan lebih cenderung membagikan dividen yang tinggi untuk menjaga reputasi di kalangan investor dan juga akan cenderung memiliki kemudahan untuk akses ke pasar modal. Kondisi tersebut akan berpengaruh terhadap perusahaan dalam akses untuk memperoleh dana dalam jumlah besar. Sehingga kondisi ini menjadikan perusahaan yang memiliki ukuran perusahaan yang besar dan memiliki tingkat pembayaran dividen yang semakin besar. Hal ini dapat dibuktikan dari sampel penelitian menunjukkan ukuran perusahaan yang lebih besar dapat membagikan deviden yang lebih tinggi. Perusahaan pada sektor industri makanan dan minuman pada umumnya mempunyai jumlah asset yang besar, dan terbukti perusahaan yang memiliki jumlah aset lebih besar dapat membagi deviden lebih tinggi.

Besar kecilnya ukuran perusahaan menjadi salah satu indikasi penilaian yang dapat dipertimbangkan investor ketika ingin melakukan investasi. Ukuran perusahaan memiliki pengaruh terhadap kebijakan dividen dikarenakan perusahaan yang memiliki ukuran yang besar akan lebih mudah memasuki pasar modal sehingga dengan metode ini perusahaan mampu membayar dividen dengan jumlah yang sesuai kepada pemegang saham. Perusahaan dengan ukuran yang besar memiliki kemudahan dalam mendapatkan modal eksternal dalam jumlah yang lebih besar terutama dari hutang. Dilain pihak, perusahaan yang masih baru dan memiliki ukuran relatif kecil akan mengalami banyak kesulitan untuk mendapatkan akses ke pasar modal (Handayani dan Hadinugroho, 2009). 


\section{Nominal: Barometer Riset Akuntansi dan Manajemen \\ P-ISSN: 2303-2065 E-ISSN: 2502-5430 \\ Volume 9 No 2 (2020)}

Ukuran atau besarnya perusahaan memainkan peranan dalam menjelaskan rasio pembayaran dividen dalam perusahaan. Perusahaan yang besar cenderung untuk lebih matang dan mempunyai akses yang lebih mudah dalam pasar modal. Kondisi tersebut akan mengurangi ketergantungan perusahaan pada penggunaan pendanaan internal, sehingga perusahaan akan cenderung melakukan pembayaran dividen yang lebih tinggi. Hasil penelitian mendukung penelitian yang telah dilakukan oleh Ahmad \& Wardani (2014), Maladjian dan Khoury (2014), Mehta (2012), yang mengungkapkan bahwa Firm Size memiliki pengaruh positif signifikan terhadap kebijakan dividen.

\section{SIMPULAN DAN SARAN}

Sektor industri makanan dan minuman merupakan salah satu sektor industri manufaktur yang mempunyai peluang untuk tumbuh dan berkembang. Kondisi tersebut terlihat dengan semakin menjamurnya industri makanan dan minuman di dalam negeri, sehingga memicu persaingan yang semakin ketat dan akibatnya para manajer perusahaan bersaing ketat dalam mencari investor untuk berinvestasi.

Hasil penelitian memperoleh bukti bahwa profitabilitas dan ukuran perusahaan berpengaruh positif signifikan terhadap kebijakan dividen, akan tetapi likuiditas berpengaruh negatif terhadap kebijakan dividen perusahaan.

Saran bagi penelitian ke depan, penelitian tidak hanya melihat dari analisis fundamental saja tetapi juga mempertimbangkan analisis teknikal. Investor tidak hanya melihat analisis fundamental perusahaan untuk memutuskan berinvestasi, namun mempertimbangkan juga analisis teknikal yang lebih berpengaruh cepat dalam pergerakan nilai saham. Menambahkan teori pendukung atau variabel tambahan, menambah periode penelitian dan jumlah sampel yang lebih besar akan mendukung hasil penelitian yang lebih akurat.

\section{DAFTAR PUSTAKA}

Aduardus dan Tandelilin. (2010). Fortofolio dan Investasi. Yogyakarta: Konisius.

Afriani, F. (2013). Pengaruh Likuiditas, Leverage, Profitabilitas, Ukuran perusahaan dan growth terhadap kebijakan dividen. Jurnal STIE Palembang

Ahmad, G. N., dan Wardani, V. K. (2014). The Effect of Fundamental Factor to Dividend Policy; Evidence in Indonesia Stock Exchange. International Journal of Business and Commerce, 4(2), 14-25

Ahmed, I. E. (2015). Liquidity, Profitability and the Dividends Payout Policy. World Review of Business Research, 5(2), 73-85

Ambarwati. (2010). Manajemen Keuangan Lanjutan. Graha Ilmu. Yogyakarta 
Ayu, T.K. (2013). Pengaruh Profitabilitas, Investment Opportunity Set, Leverage, dan Growth Terhadap Kebijakan Dividen. Jurnal Universitas Muhammadiyah Surakarta

Breadley, Myers, dan Marcus. (2007). Dasar-dasar Manajemen Keuangan. Perusahaan Edisi Kelima: Jilid 1. Terjemahan Yelpi Andri Zamur. Jakarta: Erlangga. Hal: 60.

Brigham, E.F dan Houston, Joel F. (2007). Dasar-Dasar Manajemen Keuangan, Jilid 1. Jakarta: Salemba Empat. Hal: 231.

Darmawi, H. (2012). Manajemen Perbankan. Bumi Aksara: Jakarta

Dewi, S. C. (2008). Pengaruh Kepemilikan Managerial, Kepemilikan Institusional, Kebijakan Hutang, Profitabilitas dan Ukuran Perusahaan terhadap Kebijakan Dividen. Jurnal Bisnis dan Akuntansi. Vol. 10, No. 1. Trisakti School of Management. Hal: 47-58.

Dewi, N.W.T., dan Sedana, I.B.P. (2014). Pengaruh Struktur Modal, Likuiditas Dan Pertumbuhan Terhadap Kebijakan Dviden di BEI. E-journal Manajemen. Vol. 3, No. 6. Hal: 17391752.

Fitri, R. R., Hosen, M. N., \& Muhari, S. (2016). Analysis of Factors that Impact Dividend Payout Ratio on Listed Companies at Jakarta Islamic Index. International Journal of Academic Research in accounting, Finance, and Management Sciences, 6(2), Hal: 8797.

Ghozali, I. (2011). Aplikasi Analisis Multivariate Dengan Program SPSS. Semarang: Badan Penerbit Universitas Diponegoro
Handayani, D. R. dan Hadinugroho, B. (2009). Analisis Pengaruh Kepemilikan Manajerial, Kebijakan Hutang, ROA, Ukuran Perusahaan Terhadap Kebijakan Dividen. Jurnal Fokus Manajerial. Vol.7, No. 1, Hal: 64- 71.

Hendra, S. R. P. (2009). Manajemen Keuangan dan Akutansi Untuk Eksekutif Perusahaan, Jakarta: PT. Raja Grafindo Persada. Hal: 201.

Idawati, I.A.A., dan Sudiartha, G. M. (2014). Pengaruh Profitabilitas, Likuiditas, Ukuran Perusahaan terhadap Kebijakan Dividen Perusahaan Manufaktur di BEI. E-Jurnal Manajemen Universitas Udayana, Vol 3, No 6, Hal:1604-1616.

Jensen, M.C. dan W.H. Meckling. (1976). Theory of the Firm: Managerial Behaviour, Agency Costs and Ownership Structure. Journal of Finance Economics.

Maladjian, C. dan Khoury, R.E. (2014). Determinants of the Dividend Policy: An Empirical Study on the Lebanese Listed Banks. International Journal Economics and Finance, 6(4): 240 256.

Marlim, P. dan Arifin, A. Z. (2015). Analysis of Cash Position, Debt to Equity Ratio, Return on Assets, Growth Potential, and Total Assets Turn Over Effect to Dividend Payout Ratio on Companies Listed at Indonesia Stock Exchange 2009-2011. IJABER, 13(7), 54035419.

Megginson, W.L., (1997). Corporate Finance Theory. Addison-Wesley Education Publisher, Inc.

Mehta, A. (2012). An Empirical Analysis of Determinants of Dividend Policy - 
Evidence from UAE Companies. Global Review of Acounting and Finance, 3 (1), 18-31.

Moradi, M., Salehi, M., \& Honarmand, S. (2010). Factors Affecting Dividend Policy: Empirical Evidence from UAE Companies. Poslovna Izvrsnost Zagreb, 4(1), 45-62.

Munawir, S. (2010). Analisis laporan Keuangan Edisi keempat. Cetakan Kelima. Belas. Yogyakarta: Liberty hal 2

Prihadi, T. (2013). Analisis Laporan Keuangan. Jakarta: Penerbit PPM

Ramli, N. M. (2010). Ownership Structure and Dividend Policy: Evidance from Malaysian Companies. International Review of Business Research Papers. Vol. 6, No. 1. February 2010. Hal: 170180.

Sadalia, I. (2010). Manajemen Keuangan. Medan: USU Press

Sari, E. S. (2012). Pengaruh Ukuran Perusahaan, Likuiditas Profitabilita, Pertumbuhan Persahaan, dan Kepemilikan Institusional Terhadap Kebijakan Dividend Payout Ratio (DPR). Ekombis Review.

Sari, K.A.N., dan Sudjarni, L.K. (2015). Pengaruh Likuiditas, Leverage, Pertumbuhan Perusahaan, Dan Profitabilitas Terhadap Kebijakan Dividen Pada Perusahaan Manufaktur di BEI. E-Jurnal Manajemen Unud, Vol. 4,No. 10, 2015:3346 - 3374.

Sisca, D. C. (2008). "Pengaruh Kepemilikan Managerial, Kepemilikan Institusional, Kebijakan Hutang, Profitabilitas dan Ukuran Perusahaan terhadap Kebijakan Dividen”. Jurnal Bisnis dan Akuntansi, 10.1, 47-58.
Sitanggang, J. (2012). Manajemen Keuangan Perusahaan. Jakarta : Mitra Wacana Media.

Suharli, M. (2006). Studi Empiris Mengenai Pengaruh Profitabilitas, Leverage, dan Harga Saham terhadap Jumlah Dividen Tunai. Jurnal Maksi, Vol. 6 No. 2.hal. 243-256.

Syahyunan. (2015). Manajemen Keuangan. Medan: USU Press

Widarjono, A. (2007). Ekonometrika: Teori dan Aplikasi untuk Ekonomi dan Bisnis, Edisi Kedua. Yogyakarta: Ekonisia FE Universitas Islam Indonesia. Hal. 54, 163. 254.

Yanti. (2014). Analisis Faktor-faktor yang Berpengaruh Terhadap Kebijakan Dividend Payout Ratio Pada Perusahaan Manufaktur yang Terdaftar di Bursa Efek Indonesia. Jurnal TEKUN, 5(2), Hal: 306-320 